\title{
Wildfire and harvesting effects on carbon dynamics in an oak-pine mixed forest
}

\author{
Aliye Sepken Kaptanoğlu ${ }^{(1)}$, \\ Ayten Namli ${ }^{(2)}$
}

\section{Introduction}

The increase in C stocks in forest ecosystems depends on the preservation of $C$ in tree biomass and soil against degradation. Wildfire and harvesting both affect the soil organic carbon storage by combusting organic matter, volatilization, changing soil structure, vegetation canopy, microclimatic conditions, erosion, litter layer composition, microbial population and their activity, and decomposition (Smith et al. 2008, Kara \& Bolat 2009, Mataix-Solera et al. 2009, Poirier et al. 2014, Marañón-Jiménez

\begin{abstract}
$\mathrm{CO}_{2}$ emission to the atmosphere is the main cause of global warming. The im pacts of land-use changes for agriculture and urbanisation, deforestation, and fire disturbance are attributed to the increase in $\mathrm{CO}_{2}$ emissions. Soil respiration, largely due to microbial activity, is one of the $\mathrm{CO}_{2}$ sources being released to the atmosphere. In this regard, several soil parameters related with carbon cycle, including organic matter, total $\mathrm{N}, \mathrm{C} / \mathrm{N}$ ratio, $\mathrm{CO}_{2}$ efflux, microbial biomass $C\left(C_{\text {mic }}\right)$, the $C_{\text {mic }} / C_{\text {org }}$ ratio, the metabolic quotient $q \mathrm{CO}_{2}$, and $\beta$-D glucosidase activity, were determined in a burned (harvested, $\mathrm{H}$; non-harvested, $\mathrm{NH}$ ), and its adjacent unburned (UB), mixed oak-pine forest to estimate the effects of burning and removal of residual woods. The $C_{\text {mic }}$ increased gradually with burning and harvesting after Month 9, and sharp increases were observed in all areas, likely due to the abundant rainfall after Month $12 . \mathrm{CO}_{2}$ efflux decreased in the burned areas at Months 4 and 6; however, this reversed in Month 9 . In spite of non-significant differences, we detected higher $\mathrm{CO}_{2}$ efflux values in the unburned areas compared to the burned ones, probably as a result of the drought effect observed in the burned areas up to Months 9 and 12 due to the increased soil heat. There was no significant difference between the $\mathrm{H}$ and $\mathrm{NH}$ burned areas, while both areas were different from the unburned areas in all soil parameters, except $\mathrm{CO}_{2}$ efflux and $q \mathrm{CO}_{2}$. The harvesting effect was not significant compared to the fire effect with regard to the considered soil variables, likely due to the management and protection of the burned area which allowed a fast vegetation recover. The abundance of the microbial biomass was independent of the changes in $\mathrm{CO}_{2}$ efflux and showed a negative correlation with $\beta-D$ glucosidase activity. This might be related to the variation in substrate quality, microbial composition and abundance after burning and harvesting.
\end{abstract}

Keywords: $\mathrm{CO}_{2}$ Evolution, $\beta$-D Glucosidase Activity, $q \mathrm{CO}_{2}$, Soil Microbial Biomass Carbon, Wildfire

\& Castro 2013, Akburak et al. 2017). Fire may accelerate the decomposition of organic matter $(\mathrm{OM})$, promoting $\mathrm{CO}_{2}$ emission. Logging and removal of burned trees increase the $\mathrm{CO}_{2}$ emissions (about $120 \mathrm{gr} \mathrm{C}$ $\mathrm{m}^{-2}$ in burned pine forests) and reduce the renovation capacity of Mediterranean ecosystems after the wildfire (Serrano-Ortiz et al. 2011). On the other hand, though no significant effect on total ecosystem carbon stocks was observed, a decrease was seen in carbon stored in snags and down woody material after the salvage logging in
(1) General Directorate of Forestry, Research Institute for Forest Soil and Ecology, 26160 Eskisehir (Turkey); (2) Ankara University, Soil Science Department, Ankara (Turkey)

@ Aliye Sepken Kaptanoğlu (asepken@gmail.com)

Received: Dec 04, 2019 - Accepted: Jul 08, 2020

Citation: Kaptanoglu AS, Namli A (2020). Wildfire and harvesting effects on carbon dynamics in an oak-pine mixed forest. iForest 13: 435-440. - doi: 10.3832/ifor3312-013 [online 202009-16]

Communicated by: Davide Ascoli burned sub-boreal jack pine forests (Bradford et al. 2012) The soil microflora contributes to soil $C$ storage, soil respiration and ecosystem productivity, despite representing only a small portion of the soil (Bauhus et al. 1997). Microbial biomass $C\left(C_{\text {mic }}\right)$ has been suggested as an indicator of changes in the soil (Bauhus et al. 1997) as a consequence of forest management (Bauhus \& Barthel 1995, Pietikäinen \& Fritze 1995, Ohtonen et al. 1992). Fire may alter the microbial abundance both directly by killing microbes soil surface due to heating and indirectly by modifying the community composition and environmental conditions (Docherty et al. 2011, Hart et al. 2005, Yang et al. 2020). Additionally, harvesting may affect these conditions by compacting the soil and causing increases in runoff rates and erosion (Mataix-Solera et al. 2016, García-Orenes et al. 2017). Decreases were found in microbial biomass carbon after harvest (18\%), burn (74\%), and burn-salvage (53\%) treatments (Smith et al. 2008).

The metabolic quotient $\left(q \mathrm{CO}_{2}\right)$, which is the microbial respiration/microbial biomass $C$ ratio, decreases with increasing the quality of substrate, and increases under un- 
favourable conditions (Anderson \& Domsch 1993, Wardle \& Ghani 1995, Bauhus et al. 1997, Mahía et al. 2006). Microbial parameters, including $\mathrm{C}_{\text {mic }}, q \mathrm{CO}_{2}$ and $q \mathrm{C}$, have been used in several studies (Nannipieri 1994) in order to understand the impacts of soil management or disturbance.

Soil microorganisms apply different strategies to use available $C$, such as biotic (e.g., release of extracellular enzymes) and abiotic (e.g., redox and metal complexation) mechanisms (Hibbing et al. 2010). $\beta$-D glucosidase which takes part in the degradation of cellulose, decreased in burned soils, as reported by Hernandez et al. (1997), but little is known about the harvesting effect of burned residues on this enzyme activity.

The purpose of this study was to understand the relationship between the $C$ dynamics and the microbial activity after a wildfire, and after harvesting of the residues, by using several microbial parameters, including $\mathrm{CO}_{2}$ evolution, $\mathrm{C}_{\text {mic }}, q \mathrm{CO}_{2}$, and $\beta$-D glucosidase enzyme activity. It was hypothesized that burning alters the microbial activity related to $C$ dynamics, and harvesting contributes to these changes.

\section{Materials and methods}

\section{Study area and soil sampling}

We conducted this study in a mixed pine (Pinus nigra Arnld. subsp. pallasiana Lamb.) and oak (Quercus pubescens Wild.) forest in

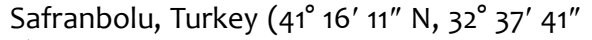
E) following a wildfire occurred on the $9^{\text {th }}$ and $10^{\text {th }}$ of October, 2011. The fire was caused by a picnic fire, and affected an area of 5 hectares. Fire severity was estimated based on the litter consumption (Ryan \& Noste 1985) and whether the ashes whiten or not (Kara \& Bolat 2009). The severity of the fire ranged from low to medium due to black ash and bare soil surface dominated the majority of the site. Additionally, this

Tab. 1 - Main soil characteristics in the study area. (EC): Electrical conductivity.

\begin{tabular}{|c|c|c|c|c|c|}
\hline & \multirow{2}{*}{ Variable } & \multicolumn{4}{|c|}{ Profile horizons } \\
\hline & & Ah & C1 & $\mathrm{C} 2$ & C3 \\
\hline \multirow{8}{*}{ 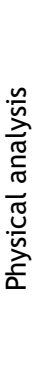 } & Depth $(\mathrm{cm})$ & $0-2$ & $2-36$ & $36-46$ & $46-83$ \\
\hline & Total weight (g) & 1614.48 & 1946.15 & 1740.84 & 2080.9 \\
\hline & Gravel weight (g) & 211.48 & 389.51 & 377.71 & 546.70 \\
\hline & Gravel volume (ml) & 87.50 & 158.33 & 155.00 & 240.00 \\
\hline & Sand (\%) & 29.41 & 37.07 & 36.97 & 42.36 \\
\hline & Silt (\%) & 29.63 & 26.95 & 21.47 & 26.42 \\
\hline & Clay (\%) & 40.97 & 35.99 & 41.56 & 31.22 \\
\hline & Soil texture & Silty clay loam & Silty clay loam & Clay loam & Clay loam \\
\hline \multirow{6}{*}{ 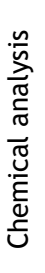 } & $\mathrm{pH} \mathrm{1:2.5}$ & 7.2 & 7.5 & 7.6 & 7.7 \\
\hline & Total lime (\%) & 2.915 & 14.84 & 28.09 & 24.11 \\
\hline & Organic Matter, OM (\%) & 6.88 & 1.65 & 1.07 & 0.87 \\
\hline & Total Nitrogen, $\mathrm{N}_{\mathrm{t}}(\%)$ & 0.39 & 0.09 & 0.06 & 0.04 \\
\hline & $\mathrm{P}_{2} \mathrm{O}_{5}\left(\mathrm{mg} \mathrm{kg}^{-1}\right)$ & 9.73 & 16.8 & 11.2 & 9.05 \\
\hline & $\mathrm{EC}\left(\times 10^{3}, \mathrm{mS} \mathrm{cm}^{-1}\right)$ & 0.70 & 0.59 & 0.41 & 0.71 \\
\hline
\end{tabular}

maining $\mathrm{NaOH}$ was titrated with $\mathrm{HCl}$ after adding $\mathrm{BaCl}_{2}$ solution and phenolphthalein. The $\mathrm{CO}_{2}$ flux was calculated from the amount of consumption of $\mathrm{HCl}$ through titration given by the following formula (eqn. 1):

$$
\mathrm{CO}_{2}(\mathrm{mg}) / \mathrm{SW} / \mathrm{t}=\frac{\left(V_{0}-V\right) \cdot 1.1}{d w t}
$$
nual rainfall was between 630 and $650 \mathrm{~mm}$ in the region during the study period. The elevation of the area was $720-760 \mathrm{~m}$ a.s.l., and the slope $30-45 \%$. The soil with typical A-C horizons belongs to the order intrazonal and suborder calsimorfic and was classified as a rendzina, according to $\mathrm{FAO} /$ UNESCO (IUSS-WRB 2014, Soil Survey Staff 2014). The main characteristics of the soils in the study area are given in Tab. 1. The area was covered with residues, consisting of twigs, for the protection of the soil and the new generation. In several parts of the burnt area the residual trees were removed (harvested).

Soil sampling was conducted in Months 4, $6,9,12$ and 24 after the fire. We selected 22 plots $\left(10 \times 10 \mathrm{~m}^{2}\right)$ including eight burnednon harvested (NH), eight burned-harvested $(\mathrm{H})$ and three adjacent, unburned areas for each species. Three soil samples per plot were collected at depths of 0-7.5 cm, following removal of the surface residues, including oak leaves and pine needles. We collected the samples from low- and medium-severity burned areas in order to achieve homogeneity. Soil samples were transferred to the laboratory, sieved through a 2-mm mesh and stored at $+4{ }^{\circ} \mathrm{C}$.

\section{Laboratory analyses}

The $\mathrm{CO}_{2}$ evolution was determined according to the method of Isermeyer (1952), modified by Alef (1995). Following incubation of the samples with $\mathrm{NaOH}$ traps for 24 hours at $25^{\circ} \mathrm{C}$ in sealed containers, the re-

where SW is the amount of soil dry weight, $t$ is the incubation time, $V_{o}$ is the $\mathrm{HCl}$ used for titration, $V$ is the $\mathrm{HCl}$ used for soil sample, $d w t$ is the dry weight of $1 \mathrm{~g}$ moist soil, and 1.1 is the conversion factor (i.e., $1 \mathrm{ml}$ $0.05 \mathrm{M} \mathrm{NaOH}$ equals $1.1 \mathrm{mg} \mathrm{CO}_{2}$ ).

The $C_{\text {mic }}$ was determined according to the chloroform extraction method described by Vance et al. (1987). Half of each sample was fumigated with $\mathrm{CHCl}_{3}$ and then incubated at $25^{\circ} \mathrm{C}$ for $24 \mathrm{~h}$. The fumigated and non-fumigated samples were extracted using $0.5 \mathrm{M} \mathrm{K}_{2} \mathrm{SO}_{4}$ at a soil/extract ratio of $1: 4$, and then kept at $-20^{\circ} \mathrm{C}$ until they were analysed using a TOC-L ${ }^{\otimes}$ analyser (Shimadzu Corp., Kyoto, Japan). The $C_{\text {mic }}$ was calculated following Wu et al. (1990) using the following equation (eqn. 2):

$$
\text { Biomass } C=2.22 \cdot E C
$$

where $E c$ is the difference between the amount of $\mathrm{C}_{\text {org }}$ extracted from the fumigated and non-fumigated soils.

The $\mathrm{qCO}_{2}$ (metabolic quotient) is a specific respiration rate of $\mathrm{CO}_{2} \mathrm{C}$ evolved per unit of $\mathrm{C}_{\text {mic }}$, which is calculated from $\mathrm{CO}_{2}$ evolution and $\mathrm{C}_{\text {mic }} \mathrm{C}$.

The $\beta$-D glucosidase activity was measured according to the method of Naseby \& Lynch (1997). A $1.5 \mathrm{~g}$ aliquot of soil was extracted using an acetate buffer at $\mathrm{pH}$ 5.5, agitated on an orbital rotary shaker with a slope angle of $60^{\circ}$ to the horizontal for $1 \mathrm{~h}$, and then centrifuged at $4000 \mathrm{rpm}$ for 15 min. Following incubation at $37^{\circ} \mathrm{C}$ for $24 \mathrm{~h}$ with buffered substrate $p$-nitrophenyl- $\beta-D$ glucoside, $1 \mathrm{ml} \mathrm{NaOHCO}$ was added to the extracts, which were then quantified at $400 \mathrm{~nm}$ in a spectrophotometer.

\section{Statistical analyses}

Differences between the burned $(\mathrm{H}$ and $\mathrm{NH}$ ) and unburned soil samples were determined by ANOVA for each period and in total. Data was transformed when it was not normally distributed as $\log \left(1+\mathrm{VqCO}_{2}\right)$, or alternatively a non-parametric test (MannWhitney $U$ ) was used. Correlations between the parameters were estimated. All statistical analyses were performed using the software $\mathrm{SPSS}^{\circledast}$ v. 21 (IBM, Armonk, NY, USA).

\section{Results}

We observed significant differences in most of the soil samples in terms of burning, while the harvested and non-harvested samples were similar for most of the variables analysed. A significant decrease was determined in $\mathrm{C}_{\text {org }}$ in burned samples but the results were relatively higher in 

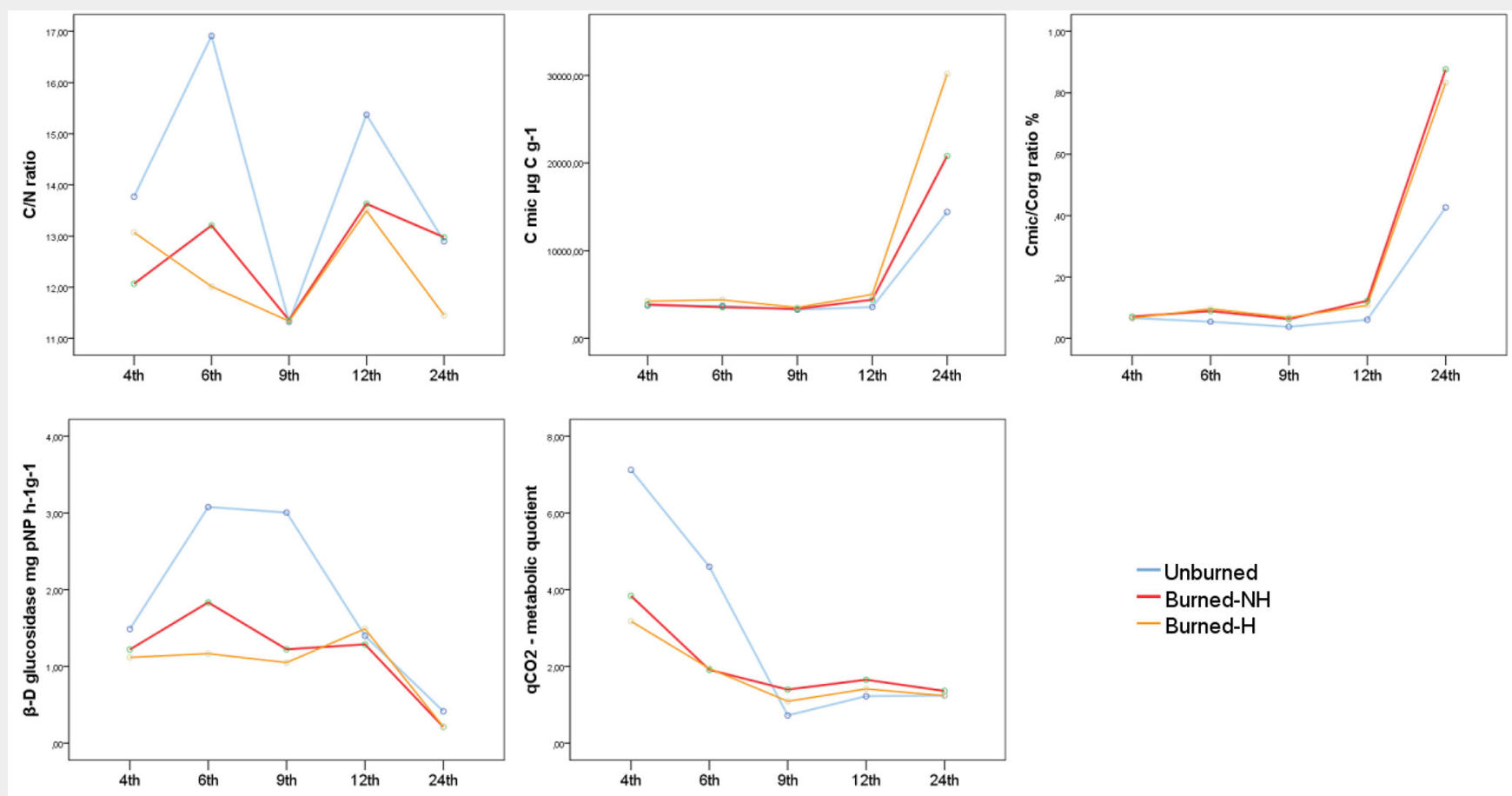

Fig. 1 - (a) $C / N$ ratio, (b) $C_{\text {mic }}$ values, (c) $C_{\text {mic }} / C_{\text {org }}$ ratio, (d) $\beta$-D glucosidase activity, and (e) $q \mathrm{CO}_{2}$ ratios in burned (H: harvested; $\mathrm{NH}$ : non-harvested) and unburned areas.

Tab. 2 - Means ( \pm standard error) of the soil parameters analysed for different periods after fire (Month) and level of disturbance (Dist). Different letters indicate significant differences $(p<0.05)$ between unburned (UB), burned non-harvested $(B-N H)$ and burned harvested $(B-H)$ areas. $(\mathrm{OM})$ : organic matter $(\%) ;\left(\mathrm{N}_{\mathrm{t}}\right)$ : total nitrogen; $\left(\mathrm{C}_{\mathrm{mic}}\right)$ : microbial carbon $\left(\mu \mathrm{gg} \mathrm{C} \mathrm{g}^{-1}\right)$; $\left(\mathrm{C}_{\text {org }}\right)$ : organic carbon; $(\beta-\mathrm{DG})$ : $\beta$-D glucosidase (mg pNP h-1 $\left.\mathrm{g}^{-1}\right) ;(\mathrm{N})$ : sample size.

\begin{tabular}{|c|c|c|c|c|c|c|c|c|c|c|}
\hline 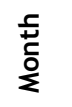 & $\ddot{n}$ & $\begin{array}{l}O M \\
(\%)\end{array}$ & $\begin{array}{l}\mathrm{N}_{\mathrm{t}} \\
(\%)\end{array}$ & $\begin{array}{l}\mathrm{C} / \mathrm{N} \\
\text { ratio }\end{array}$ & $\begin{array}{c}\mathrm{CO}_{2} \text { efflux } \\
\left(\mathrm{mg} \mathrm{CO}_{2}\right. \\
\left.\mathrm{g}^{-1} \mathrm{~h}^{-1}\right)\end{array}$ & $\begin{array}{c}C_{\text {mic }} \\
\left(\mu g \mathrm{Cg}^{-1}\right)\end{array}$ & $\begin{array}{c}C_{\text {mic }} / C_{\text {org }} \\
\text { ratio }\end{array}$ & $\begin{array}{c}q \mathrm{CO}_{2} \\
\left(\mathrm{mg} \mathrm{CO}_{2} \mathrm{~g}^{-1}\right. \\
\left.\mathrm{Cmic} \mathrm{h}^{-1}\right)\end{array}$ & $\begin{array}{c}\beta-D G \\
(m g \text { pNP } \\
\left.h^{-1} \mathrm{~g}^{-1}\right)\end{array}$ & $N$ \\
\hline \multirow[t]{4}{*}{4} & UB & $6.09 \pm 1.48^{a}$ & $0.26 \pm 0.07^{a}$ & $14 \pm 1^{b}$ & $19.81 \pm 6.11^{\mathrm{a}}$ & $3760 \pm 2239^{a}$ & $0.07 \pm 0.04^{a}$ & $7.12 \pm 5.23^{b}$ & $1.49 \pm 0.32^{a}$ & 6 \\
\hline & B-NH & $5.49 \pm 1.72^{a}$ & $0.27 \pm 0.09^{a}$ & $12 \pm 1^{\mathrm{a}}$ & $13.45 \pm 2.88^{a}$ & $3862 \pm 1200^{a}$ & $0.07 \pm 0.02^{a}$ & $3.84 \pm 1.52^{a}$ & $1.22 \pm 0.97^{a}$ & 8 \\
\hline & B-H & $6.50 \pm 1.60^{\mathrm{a}}$ & $0.29 \pm 0.09^{a}$ & $13 \pm 2^{a b}$ & $14.36 \pm 9.89^{a}$ & $4251 \pm 1489^{a}$ & $0.07 \pm 0.02^{a}$ & $3.18 \pm 0.96^{\mathrm{a}}$ & $1.12 \pm 0.84^{\mathrm{a}}$ & 8 \\
\hline & Total & $6.02 \pm 1.60$ & $0.28 \pm 0.08$ & $13 \pm 1$ & $15.51 \pm 7.19$ & $3976 \pm 1568$ & $0.07 \pm 0.02$ & $4.50 \pm 3.22$ & $1.26 \pm 0.77$ & 22 \\
\hline \multirow[t]{4}{*}{6} & UB & $6.57 \pm 1.22^{b}$ & $0.25 \pm 0.08^{a}$ & $17 \pm 8^{a}$ & $8.88 \pm 2.15^{b}$ & $3703 \pm 2533^{a}$ & $0.05 \pm 0.03^{a}$ & $4.60 \pm 4.45^{\mathrm{a}}$ & $3.08 \pm 3.32^{a}$ & 6 \\
\hline & B-NH & $4.14 \pm 0.84^{\mathrm{a}}$ & $0.19 \pm 0.04^{\mathrm{a}}$ & $13 \pm 4^{\mathrm{a}}$ & $5.52 \pm 1.06^{a}$ & $3555 \pm 1777^{a}$ & $0.09 \pm 0.04^{\mathrm{a}}$ & $1.91 \pm 1.05^{\mathrm{a}}$ & $1.84 \pm 1.94^{\mathrm{a}}$ & 8 \\
\hline & B-H & $5.15 \pm 2.18^{a b}$ & $0.24 \pm 0.06^{a}$ & $12 \pm 3^{a}$ & $6.53 \pm 2.20 \mathrm{ab}$ & $4393 \pm 3056^{a}$ & $0.10 \pm 0.07^{a}$ & $1.95 \pm 0.85^{a}$ & $1.17 \pm 0.85^{a}$ & 8 \\
\hline & Total & $5.17 \pm 1.77$ & $0.23 \pm 0.06$ & $14 \pm 5$ & $6.80 \pm 2.23$ & $3900 \pm 2417$ & $0.08 \pm 0.05$ & $2.66 \pm 2.61$ & $1.93 \pm 2.17$ & 22 \\
\hline \multirow[t]{4}{*}{9} & UB & $8.37 \pm 3.16^{b}$ & $0.43 \pm 0.17^{b}$ & $11 \pm 0^{a}$ & $1.96 \pm 0.93^{a}$ & $3276 \pm 1872^{a}$ & $0.04 \pm 0.01^{a}$ & $0.73 \pm 0.41^{a}$ & $3.01 \pm 1.36^{b}$ & 6 \\
\hline & B-NH & $5.37 \pm 1.40^{\mathrm{a}}$ & $0.27 \pm 0.07^{\mathrm{a}}$ & $11 \pm 0^{a}$ & $3.70 \pm 1.58^{a}$ & $3357 \pm 1428^{a}$ & $0.06 \pm 0.02^{a}$ & $1.40 \pm 1.10^{a}$ & $1.22 \pm 1.06{ }^{a b}$ & 8 \\
\hline & B-H & $5.73 \pm 2.55^{a b}$ & $0.29 \pm 0.13$ ab & $11 \pm 0^{a}$ & $3.25 \pm 2.03^{a}$ & $3522 \pm 1590^{a}$ & $0.07 \pm 0.04^{a}$ & $1.09 \pm 0.82^{a}$ & $1.05 \pm 0.64^{a}$ & 8 \\
\hline & Total & $6.32 \pm 2.62$ & $0.32 \pm 0.14$ & $11 \pm 0$ & $3.06 \pm 1.71$ & $3395 \pm 1539$ & $0.06 \pm 0.03$ & $1.11 \pm 0.86$ & $1.65 \pm 1.30$ & 22 \\
\hline \multirow[t]{4}{*}{12} & UB & $6.18 \pm 1.11^{\mathrm{a}}$ & $0.24 \pm 0.05^{\mathrm{a}}$ & $15 \pm 2^{a}$ & $4.21 \pm 1.30^{\mathrm{a}}$ & $3575 \pm 7880^{a}$ & $0.06 \pm 0.02^{a}$ & $1.23 \pm 0.51^{\mathrm{a}}$ & $1.40 \pm 0.36^{a}$ & 6 \\
\hline & B-NH & $4.40 \pm 1.99^{a}$ & $0.19 \pm 0.06^{a}$ & $14 \pm 5^{a}$ & $6.95 \pm 2.56^{a}$ & $4415 \pm 1023$ ab & $0.12 \pm 0.06^{b}$ & $1.66 \pm 0.66^{a}$ & $1.29 \pm 1.34^{\mathrm{a}}$ & 8 \\
\hline & B-H & $4.88 \pm 1.28^{a}$ & $0.22 \pm 0.06^{a}$ & $13 \pm 3^{a}$ & $6.59 \pm 2.86^{a}$ & $5009 \pm 1359^{b}$ & $0.11 \pm 0.03^{a b}$ & $1.42 \pm 0.75^{\mathrm{a}}$ & $1.49 \pm 1.19^{a}$ & 8 \\
\hline & Total & $5.06 \pm 1.64$ & $0.21 \pm 0.06$ & $14 \pm 4$ & $6.07 \pm 2.59$ & $4402 \pm 1203$ & $0.10 \pm 0.05$ & $1.45 \pm 0.65$ & $1.39 \pm 1.05$ & 22 \\
\hline \multirow[t]{4}{*}{24} & UB & $4.52 \pm 2.08^{a}$ & $0.21 \pm 0.12^{a}$ & $13 \pm 2^{a}$ & $9.47 \pm 2.57^{\mathrm{a}}$ & $14417 \pm 15842^{a}$ & $0.43 \pm 0.52^{a}$ & $1.24 \pm 0.87^{\mathrm{a}}$ & $0.42 \pm 0.24^{\mathrm{a}}$ & 6 \\
\hline & B-NH & $3.57 \pm 1.43^{a}$ & $0.16 \pm 0.05^{a}$ & $13 \pm 3^{a}$ & $8.86 \pm 1.92^{a}$ & $20805 \pm 20733^{a}$ & $0.88 \pm 1.07^{a}$ & $1.36 \pm 1.25^{a}$ & $0.21 \pm 0.17^{a}$ & 8 \\
\hline & B-H & $4.00 \pm 0.84^{\mathrm{a}}$ & $0.21 \pm 0.05^{a}$ & $11 \pm 3^{a}$ & $9.13 \pm 1.99^{a}$ & $30156 \pm 28705^{a}$ & $0.83 \pm 0.82^{a}$ & $1.24 \pm 1.39^{a}$ & $0.22 \pm 0.15^{a}$ & 8 \\
\hline & Total & $3.99 \pm 1.45$ & $0.19 \pm 0.08$ & $12 \pm 3$ & $9.12 \pm 2.04$ & $22463 \pm 22799$ & $0.74 \pm 0.84$ & $1.29 \pm 1.16$ & $0.27 \pm 0.20$ & 22 \\
\hline \multirow[t]{4}{*}{ Total } & UB & $6.35 \pm 2.21^{b}$ & $0.28 \pm 0.13^{a}$ & $14 \pm 4^{b}$ & $8.87 \pm 6.93^{a}$ & $5746 \pm 8088^{a}$ & $0.13 \pm 0.26^{a}$ & $2.98 \pm 3.84^{a}$ & $1.88 \pm 1.83^{b}$ & 30 \\
\hline & B-NH & $4.59 \pm 1.62^{a}$ & $0.22 \pm 0.08^{a}$ & $13 \pm 3^{a}$ & $7.69 \pm 3.93^{a}$ & $7199 \pm 11231^{b}$ & $0.24 \pm 0.56^{b}$ & $2.03 \pm 1.44^{\mathrm{a}}$ & $1.16 \pm 1.29^{a}$ & 40 \\
\hline & B-H & $5.25 \pm 1.90^{\mathrm{a}}$ & $0.25 \pm 0.09^{a}$ & $12 \pm 2^{a}$ & $7.97 \pm 5.95^{\mathrm{a}}$ & $9466 \pm 16148^{b}$ & $0.23 \pm 0.46^{b}$ & $1.78 \pm 1.20^{a}$ & $1.01 \pm 0.88^{a}$ & 40 \\
\hline & Total & $5.31 \pm 2.01$ & $0.25 \pm 0.1$ & $13 \pm 3$ & $8.11 \pm 5.58$ & $7627 \pm 12574$ & $0.21 \pm 0.46$ & $2.20 \pm 2.33$ & $1.30 \pm 1.38$ & 110 \\
\hline
\end{tabular}


Tab. 3 - Correlation coefficients among the analyzed soil parameters $(n=110)$. $\left(N_{t}\right)$ : total nitrogen; $\left(C_{\text {mic }}\right)$ : microbial carbon; $\left(C_{\text {org }}\right)$ : organic carbon; $(\beta-D G)$ : $\beta$-D glucosidase; $\left({ }^{*}\right)$ : $p<0.05 ;(* *): p<0.001 ;(n s)$ : non-significant.

\begin{tabular}{lllllllll}
\hline- & $\mathrm{C}_{\text {org }}$ & $\mathrm{N}_{\mathrm{t}}$ & $\mathrm{C} / \mathrm{N}$ & $\mathrm{CO}_{2}$ efflux & $\mathrm{C}_{\text {mic }}$ & $\mathrm{C}_{\text {mic }} / \mathrm{C}_{\text {org }}$ & $q \mathrm{CO}_{2}$ & $\beta-D G$ \\
\hline $\mathrm{C}_{\text {org }}$ & 1 & $0.873^{* *}$ & $0.207^{*}$ & $0.128^{\mathrm{ns}}$ & $-0.277^{* *}$ & $-0.384^{* *}$ & $0.135^{\mathrm{ns}}$ & $0.181^{\mathrm{ns}}$ \\
$\mathrm{N}_{\mathrm{t}}$ & - & 1 & $-0.274^{* *}$ & $0.078^{\mathrm{ns}}$ & $-0.266^{* *}$ & $-0.341^{* *}$ & $0.106^{\mathrm{ns}}$ & $0.143^{\mathrm{ns}}$ \\
$\mathrm{C} / \mathrm{N}$ & - & - & 1 & $0.055^{\mathrm{ns}}$ & $-0.001^{\mathrm{ns}}$ & $-0.076^{\mathrm{ns}}$ & $0.000^{\mathrm{ns}}$ & $0.097^{\mathrm{ns}}$ \\
$\mathrm{CO}_{2}$ efflux & - & - & - & 1 & $0.046^{\mathrm{ns}}$ & $0.011^{\mathrm{ns}}$ & $0.592^{* *}$ & $-0.154^{\mathrm{ns}}$ \\
$\mathrm{C}_{\text {mic }}$ & - & - & - & - & 1 & $0.925^{* *}$ & $-0.298^{* *}$ & $-0.241^{*}$ \\
\hline $\mathrm{C}_{\text {mic }} / \mathrm{C}_{\text {org }}$ & - & - & - & - & - & 1 & $-0.274^{* *}$ & $-0.241^{*}$ \\
\hline $\mathrm{qCO}_{2}$ & - & - & - & - & - & - & 1 & $-0.024^{\mathrm{ns}}$ \\
$\beta-\mathrm{DGG}$ & - & - & - & - & - & - & - & 1 \\
\hline
\end{tabular}

burned-H samples. No difference in total nitrogen $\left(\mathrm{N}_{\mathrm{t}}\right)$ was found between the unburned and burned soils but the Month 9 . The $\mathrm{C} / \mathrm{N}$ ratios were slightly different in favor of the unburned samples $(p=0.05$ Fig. 1a, Tab. 2). There was no significant difference in $\mathrm{CO}_{2}$ evolution ( $\left.p=0.956\right)$; however, the maximum values were observed in the unburned soils, and the minimum values were found in the burned-NH soils (Tab. 2). The $C_{\text {mic }}$ values were different at Month $12(p=0.036)$ while it was comparatively high in the burned areas at all months (Fig. 1b, Tab. 2). We observed significant differences $(p=0.029)$ in $C_{\text {mic }} / C_{\text {org }}$ at Month 12 similarly (Fig. 1c, Tab. 2). An increase in the total amount of $C_{\text {mic }}$ in all areas was observed through the time, but the increase was higher in the burned areas between Months 12 and 24 .

Significant differences were observed between the burned and unburned areas $(p=$ 0.023 ) in favor of unburned areas in regard to $\beta$-D glucosidase enzyme activity (Fig. 1d, Tab. 2). The $\mathrm{qCO}_{2}$ values did not vary significantly with burning $(p=0.786)$ except for Month 4 (Fig. 1e, Tab. 2).

There were significant differences between the different periods, in terms of the soil properties, with $\mathrm{p}<0.05$ for $\mathrm{C} / \mathrm{N}$ and $\beta$ $D$ glucosidase, and $p<0.001$ for the others. The interaction effect of period and burning for $q \mathrm{CO}_{2}$ was significant $(p<0.05)$, while it was unclear for $\mathrm{CO}_{2}$ evolution $(\mathrm{p}=$ 0.052).

$C_{\text {mic }}$ and $C_{\text {mic }} / C_{\text {org }}$ were well correlated with each other, while negative relations between $\mathrm{C}_{\mathrm{org}}, \mathrm{TN}, \mathrm{qCO}_{2}$ and $\beta$-D glucosidase were recorded (Tab. 3).

\section{Discussion}

Although the $C_{\text {org }}, C / N, C_{\text {mic }}, C_{\text {mic }} / C_{\text {org }}$ and $\beta$ $D$ glucosidase values were different between the burned and unburned plots, there were no significant differences between the $\mathrm{H}$ (burned, harvested) and $\mathrm{NH}$ (burned, non-harvested) areas, in terms of the soil parameters.

Organic carbon content decreases as a result of fire as observed in this study, and changes may occur in organic matter fractions. As a matter of fact, loss of $\mathrm{C}_{\text {org }}$ and $\mathrm{N}_{t}$ has been reported due to the fire severity reaching $220-460{ }^{\circ} \mathrm{C}$ (Giovannini et al. 1990 , DeBano et al. 1998). Similarly, the lower levels of OM were significant at Month 6 and 9 according to our results. Relatively high OM content in burned-harvested samples was likely due to mixing of the forest floor with the mineral soil during harvesting (Poirier et al. 2014). $N_{t}$ content in burned samples were low as well as nonsignificant in general. Higher $\mathrm{N}_{t}$ concentration was observed at Month 9 likely due to the warmer conditions in more moist unburned samples (Jaeger et al. 1999, Kaiser et al. 2011, Yokobe et al. 2018). Slight changes in $\mathrm{C} / \mathrm{N}$ ratio may be related with the formation of new recalcitrant $\mathrm{N}$ and volatisation of $\mathrm{C}$ compounds, as suggested by previous studies conducted in burned pine forests (Rodríguez et al. 2017, GómezSánchez et al. 2019).

A general increase in $C_{\text {mic }}$ was probably due to the increase in the concentration of oxidisable $C$ and nutrients in burned soils as previously reported (Gómez-Sánchez et al. 2019, Giuditta et al. 2020); immediate increases have been found in soils after fire (Turgay et al. 2002, Dooley \& Treseder 2012). Likely because of the relatively late sampling in our study, we did not detect significant changes in the above variables in burned (especially burned and harvested) areas in Month 4 and Month 6 . Bárcenas-Moreno et al. (2011) categorised the process of microbial recovery after a wildfire as initial depletion of microorganisms in soil and the proliferation of fastgrowing bacteria after a few months due to rapid and short increase of available nutrients. $C_{\text {mic }}$ increase was reported after 8 months in a burned pine (Pinus halepensis) and oak (Quercus coccifera) mixed forest by Bárcenas-Moreno et al. (2011) which was maintained for the rest of their study and reversed after 32 months. We assessed a significant decrease at Month 12 and nonsignificant decrease at Month 24 in $\mathrm{C}_{\text {mic }}$ values of the unburned areas, in comparison with those at Months 4 and 6 . An increase in the total amount of $C_{\text {mic }}$ was observed in all areas, more in the burned areas, likely due to the higher amount of rainfall between Months 12 and 24.

We found a negative correlation between
$\mathrm{C}_{\text {mic }}$ and $\mathrm{qCO}_{2}$ that is inconsistent with the results from previous studies (Wardle \& Ghani 1995, Bolat \& Oztürk 2017), whereas a positive correlation between $\mathrm{C}_{\text {mic }}$ and $\mathrm{CO}_{2}$ evolution was detected. A high $\mathrm{qCO}_{2}$ indicates the need for restoring the $\mathrm{C}$ demand as a result of the microbial biomass depending on the renewal of $C$ lost through respiration (Anderson \& Domsch 2010, Bolat \& Oztürk 2017). After a low-intensity prescribed fire in a Picea abies forest, basal respiration diminished while there was a disproportionate decrease in $\mathrm{C}_{\text {mic }}$ (Pietikäinen \& Fritze 1995), which clearly led to higher values of $\mathrm{qCO}_{2}$ in the burned areas compared to unburned ones (Certini 2005). This indicator predicts soil fertility (Anderson \& Domsch 1993, Wardle \& Ghani 1995, Bauhus et al. 1997, Mahía et al. 2006, Bolat 2014). The lower levels of $\mathrm{qCO}_{2}$ in the burned soils in the first and second sampling dates indicate an improvement in soil conditions for the new vegetation due to the warmer soils in burned areas. Similar values in the burned and unburned areas after Month 9 may have resulted from vegetation succession (Insam \& Haselwandter 1989).

$\beta$-D glucosidase enzyme activity plays an important role in energy availability in the soil, as it is directly related to the labile $C$ content and its ability to stabilise the soil organic matter independently of seasonal variability (Martinez-Salgado et al. 2010). Our results indicate that this enzyme activity decreased with burning up to the last sampling date, two years after the wildfire, and was significantly different among $\mathrm{H}$, $\mathrm{NH}$, and UB plots at Month 9. The decrease in enzyme activity related with the lack of $C$ entry to the system via plant inputs of $C_{\text {org }}$ and $\mathrm{N}_{\mathrm{t}}$ (Sinsabaugh \& Moorhead 1994, Sinsabaugh et al. 2008) is consistent with our results. There was a negative correlation between enzyme activity and $C_{\text {mic }}$. The decrease in enzyme activity compared to $C_{\text {mic }}$ likely resulted from the enzymes being retained in the stabilised fraction of the soil rather than that part associated with the viable microbial population (Knight \& Dick 2004).

Decomposition increased due to harvesting, possibly resulting in changes to the $C$ budget (Noormets et al. 2015). The harvesting of burned tree residues did not affect the measured soil parameters significantly in this study, probably because of the sensitive protection precautions used after the wildfire (such as covering the soil surface with residual brushwood material) and the rapid regeneration of forest (Gömöryová et al. 2017, Gómez-Sánchez et al. 2019), which is characteristic of oak forests.

\section{Conclusions}

Fire affected the microbial biomass likely due to changes in the substrate quality, microbial composition, and abundance. However, this increase was not significant one year after burning. The correlation between $\mathrm{qCO}_{2}$ and $\beta$-D glucosidase activity 
showed that the former might be a more coherent indicator of microbial functionality than $\mathrm{C}_{\text {mic }}$ and $\mathrm{CO}_{2}$ evolution. In fact, enzymes might be independent of microbial proliferation, as it can attach to dead cells or cellular fragments instead of viable microorganisms.

The decrease in $\mathrm{qCO}_{2}$ after burning at low severity may indicate to the forest managers that the soil has relatively ideal conditions, simplifying the preparation of the area for new vegetation. The harvesting of burned trees in post-fire areas provides many advantages, in terms of economic benefits or protection of the forest against pests. Proper precautions for the soil, such as covering it after the fire with residues, comprising branches and small, felled burned trees, may be advantageous by allowing soil and nutrient loss to be avoided.

\section{Acknowledgements}

This study was supported by the General Directorate of Forestry of Turkey. All the analyses were conducted at the Research Institute for Forest Soil and Ecology in the context of project ESK-11 (6300)/2011-2015. Part of the data for some of the soil characteristics were used in the publication Kaptanoglu \& Namli (2019), for different periods and in a different context. We would like to thank Aydin Çömez, Oğuz Can Turgay, Münevver Arslan, and Kürşad Özkan for their comments.

\section{References}

Akburak S, Son Y, Makineci E, Cakir M (2017). Impacts of low-intensity prescribed fire on microbial and chemical properties in a Quercus frainetto forest. Journal of Forestry Research 29: 687-696. - doi: 10.1007/s11676-017-0486-4

Alef K (1995). Soil respiration. In: "Methods in Applied Soil Microbiology and Biochemistry" (Alef K, Nannipieri P eds). Academic Press, London, UK, pp. 214-219.

Anderson TH, Domsch KH (1993). The metabolic quotient for $\mathrm{CO}_{2}\left(\mathrm{qCO}_{2}\right)$ as a specific activity parameter to assess the effects of environmental conditions, such as $\mathrm{pH}$, on the microbial biomass of forest soils. Soil Biology and Biochemistry 25: 393-395. - doi: 10.1016/0038-0717(93)90 140-7

Anderson TH, Domsch KH (2010). Soil microbial biomass: the eco-physiological approach. Soil Biology and Biochemistry 42 (12): 2039-2043. doi: 10.1016/j.soilbio.2010.06.026

Bauhus J, Barthel R (1995). Mechanisms for carbon and nutrient release and retention within beech forest gaps. II. The role of soil microbial biomass. Plant and Soil 168: 585-592. - doi: 10.10 07/BFo0029372

Bauhus J, Parè D, Côtè L (1997). Effects of tree species, stand age, and soil type on soil microbial biomass and its activity in a southern boreal forest. Soil Biology and Biochemistry 30 (89): 1077-1089. - doi: 10.1016/So038-0717(97)002 13-7

Bolat I (2014). The effect of thinning on microbial biomass $\mathrm{C}, \mathrm{N}$ and basal respiration in black pine forest soils in Mudurnu, Turkey. European Journal of Forest Research 133: 131-139. - doi: 10.100 7/s10342-013-0752-8

Bolat I, Oztürk M (2017). Effects of altitudinal gradients on leaf area index, soil microbial biomass $\mathrm{C}$ and microbial activity in a temperate mixed forest ecosystem of Northwestern Turkey. iForest - Biogeosciences and Forestry 10: 334-340. - doi: 10.3832/ifor1974-009

Bárcenas-Moreno G, García-Orenes F, MataixSolera J, Mataix-Beneyto J, Bååth E (2011). Soil microbial recolonisation after a fire in a Mediterranean forest. Biological Fertility of Soils 47: 261-272. - doi: 10.1007/s00374-010-0532-2

Bradford JB, Fraver S, Milo AM, D'Amato AW, Palik B (2012). Effects of multiple interacting disturbances and salvage logging on forest carbon stocks. Forest Ecology and Management 267: 209214. - doi: 10.1016/j.foreco.2011.12.010 Certini G (2005). Effects of fire on properties of forest soils: a review. Oecologia (2005) 143:110. - doi: 10.1007/s00442-004-1788-8

DeBano LF, Neary DG, Ffolliott PF (1998). Fire's effects on ecosystems. Wiley, New York, USA, pp. 73-78. [online] URL: http://books.google. com/books?id=cFxtriC2EDkC

Docherty KM, Balser TC, Bohannan BJM, Gutknecht JLM (2011). Soil microbial responses to fire and interacting global change factors in a California annual grassland. Biogeochemistry 109 (1-3): 63-83. - doi: 10.1007/s10533-011-9654-3 Dooley SR, Treseder KK (2012). The effect of fire on microbial biomass: a meta-analysis of field studies. Biogeochemistry 109: 49-61. - doi: 10.1007/s10533-011-9633-8

García-Orenes F, Arcenegui V, Chrenková K, Mataix-Solera J, Moltó J, Jara-Navarro AB, Torres MP (2017). Effects of salvage logging on soil properties and vegetation recovery in a fire-affected Mediterranean forest: a two year monitoring research. Science of the Total Environment 586: 1057-1065. - doi: 10.1016/j.scitotenv. 2017.02.090

Giovannini G, Lucchesi S, Giachetti M (1990). Effects of heating on some chemical parameters related to soil fertility and plant growth. Soil Science 149: 344-350. - doi: 10.1097/00010694199006000-00005

Giuditta E, Marzaioli R, Esposito A, Ascoli D, Stinca A, Mazzoleni S, Rutigliano FA (2020). Soil microbial diversity, biomass, and activity in two pine plantations of southern Italy treated with prescribed burning. Forests 11 (1): 2-19. - doi: 10.3390/f11010019

Gómez-Sánchez E, Lucas-Borja ME, Plaza-Alvarez PA, González-Romero J, Sagra J, Maya D, De Las Heras J (2019). Effects of post-fire hillslope stabilisation techniques on chemical, physicochemical and microbiological soil properties in Mediterranean forest ecosystems. Journal of Environmental Management 246: 229-238. - doi: 10.1016/j.jenvman.2019.05.150

Gömöryová E, Fleischer P, Pichler V, Homolák M, Gere R, Gömöry D (2017). Soil microorganisms at the windthrow plots: the effect of postdisturbance management and the time since disturbance. iForest - Biogeosciences and Forestry 10: 515-521. - doi: 10.3832/ifor2304-010

Hart SC, DeLuca TH, Newman GS, MacKenzie MD, Boyle SI (2005). Post-fire vegetative dynamics as drivers of microbial community structure and function in forest soils. Forest Ecology and Management 220 (1-3): 166-184. - doi: 10.101 6/j.foreco.2005.08.012

Hernandez T, Garcia C, Reinhardt I (1997). Shortterm effect of wildfire on the chemical, biochemical and microbiological properties of Mediterranean pine forest soil. Biology and Fertility of Soils 25 (2): 109-116. - doi: 10.1007/s003740 050289

Hibbing ME, Fuqua C, Parsek MR, Peterson SB (2010). Bacterial competition: surviving and thriving in the microbial jungle. Nature Reviews Microbiology 8: 15-25. - doi: 10.1038/nrmicro22 59

Insam H, Haselwandter K (1989). Metabolic quotient of the soil microflora in relation to plant succession. Oecologia 79: 174-178. - doi: 10.1007/ BFo0388474

Isermeyer H (1952). Eine Einfache Methode sur Bestimmung der Bodenatmung und der Karbonate im Boden [A simple method for determining respiration and carbonates in soil]. Zeitschrift Pflanzenernährung und Bodenkunde 56: 26-38. [in German] - doi: 10.1002/jpln.19520560 107

IUSS-WRB (2014). World reference base for soil resources 2014: International soil classification system for naming soils and creating legends for soil maps. FAO-IUSS Working Group WRB, World Soil Resources Reports no. 106, FAO, Rome, Italy, pp. 181.

Jaeger $\mathrm{CH}$, Monson RK, Fisk MC, Schmidt SK (1999). Seasonal partitioning of nitrogen by plants and soil microorganisms in an alpine ecosystem. Ecology 80: 1883-1891. - doi: 10.189 o/0012-9658(1999)080[1883:SPONBP]2.0.CO;2

Kaiser C, Fuchslueger L, Koranda M, Gorfer M, Stange CF, Kitzler B, Rasche F, Strauss J, Sessitsch A, Zechmeister S, Richter A (2011). Plants control $\mathrm{N}$ cycling the seasonal dynamics of microbial in a beech forest soil by belowground $\mathrm{C}$ allocation. Ecology 92: 1036-1051. - doi: 10.1890/ 10-1011.1

Kaptanoglu AS, Namli A (2019). Orman yangininin ve yangin sonrasi bosaltma kesimlerinin toprak özelliklerine etkisi [The effects of forest fire and post-fire salvage logging on soil properties]. Ormancilik Arastirma Dergisi [Turkish Journal of Forestry Research] 6 (1): 29-46. [in Turkish] - doi: 10.17568/ogmoad.430649 Kara O, Bolat I (2009). Short-term effects of wildfire on microbial biomass and abundance in black pine plantation soils in Turkey. Ecological Indicators 9: 1151-1155. - doi: 10.1016/j.ecolind.20 09.01 .002

Keeley JA (2009). Fire intensity, fire severity and burn severity: a brief review and suggested usage. International Journal of Wildland Fire 18: 116-126. - doi: 10.1071/WF07049

Knight T, Dick R (2004). Differentiating microbial and stabilized $\beta$-glucosidase activity relative to soil quality. Soil Biology and Biochemistry 36: 2089-2096. - doi: 10.1016/j.soilbio.2004.06.007 Mahía J, Pèrez Ventura L, Cabaneiro A, Díaz-Raviña $M$ (2006). Soil microbial biomass under pine forests in north-western Spain: influence of stand age, site index and parent material. Forest Systems 15 (2): 152-159. - doi: 10.5424/srf/20 06152-00960

Marañón-Jiménez S, Castro J (2013). Effect of decomposing post-fire coarse woody debris on soil fertility and nutrient availability in a Mediterranean ecosystem. Biogeochemistry 112: 519- 
535. - doi: 10.1007/s10533-012-9744-x

Martinez-Salgado MM, Gutiérrez-Romero V, Jannsens M, Ortega-Blu R (2010). Biological soil quality indicators: a review. In: "Current Research, Technology and Education Topics in Applied Microbiology and Microbial Biotechnology" (Mendez-Vilas A ed). World Scientific Publishing Co. Ltd., Singapore, pp. 319-328.

Mataix-Solera J, Guerrero C, García-Orenes F, Bárcenas GM, Torres MP (2009). Forest fire effects on soil microbiology. In: "Fire Effects on Soils and Restoration Strategies" (Cerdà A, Robichaud PR eds). Science Publishers Inc., Enfield, New Hampshire, USA, pp. 133-175. [online] URL: http://books.google.com/books? id=Cf6dm Fb6FWoC

Mataix-Solera J, Arnaiz P, Arcenegui V, Chrenkovà K, López-Caravaca A, García-Orenes F, Jara-Navarro AB, Cerdà A (2016). Hydrological response 3 years after salvage logging treatments in a recently burnt forest soil. In: Proceedings of the European Society for Soil Conservation Conference. Cluj-Napoca (Romania) 15-18 Jun 2016, Abstracts Book, pp. 47.

Nannipieri P (1994). The potential use of soil enzymes as indicators of productivity, sustainability and pollution. In: "Soil Biota: Management and Sustainable Farming Systems" (Pankhurst CE, Doube BM, Gupta VSR, Grace PR eds). CSIRO, East Melbourne, Australia, pp. 238-244. Naseby DC, Lynch JM (1997). Rhizopshere soil enzymes as indicators of perturbation caused by enzyme substrate addition and inoculation of a genetically modified strain of Pseudomonas fluorescens on wheat seed. Soil Biology and Biochemistry 29: 1353-1362. - doi: 10.1016/So 038-0717(97)00061-8

Noormets A, Epron D, Domec JC, McNulty SG, Fox T, Sun G, King JS (2015). Effects of forest management on productivity and carbon sequestration: a review and hypothesis. Forest Ecology and Management 355: 124-140. - doi: 10.1016/j.foreco.2015.05.019

Ohtonen R, Munson A, Brand D (1992). Soil microbial community response to silvicultural intervention in coniferous plantation ecosystems. Ecological Applications 2: 363-375. - doi: 10.2307/1941871

Pietikäinen J, Fritze H (1995). Clear-cutting and prescribed burning in coniferous forest: com- parison of effects on soil fungal and total microbial biomass, respiration activity and nitrification. Soil Biology and Biochemistry 27: 101109. - doi: 10.1016/0038-0717(94)00125-K

Poirier V, Paré D, Boiffin J, Munson AD (2014). Combined influence of fire and salvage logging on carbon and nitrogen storage in boreal forest soil profiles. Forest Ecology and Management 326: 133-141. - doi: 10.1016/j.foreco.2014.04.021

Rodríguez J, González-Pérez JA, Turmero A, Hernández $M$, Ball $A S$, González-Vila FJ, Arias ME (2017). Wildfire effects on the microbial activity and diversity in a Mediterranean forest soil. Catena 158: 82-88. - doi: 10.1016/j.catena.2017.06. 018

Ryan KC, Noste NV (1985). Evaluating prescribed fires. In: Proceedings of the "Symposium and Workshop on Wilderness Fire" (Lotan JE, Kilgore BM, Fischer WC, Mutch RW eds). Missoula (NT, USA) 15-18 Nov 1983. General Technical Report INT-182, USDA Forest Service, Intermountain Forest and Range Experiment Station, Ogden, UT, USA, pp. 230-238. - [online] URL: http://citeseerx.ist.psu.edu/viewdoc/download? doi=10.1.1.879.9469\&rep=rep1\&type=pdf

Ryan KC (2002). Dynamic interactions between forest structure and fire behavior in boreal ecosystems. Silva Fennica 36: 13-39. - doi: 10.142 14/sf. 548

Serrano-Ortiz P, Marañón-Jiménez $S$, Reverter BR, Sánchez-Cañete EP, Castro J, Zamora R, Kowalski AS (2011). Post-fire salvage logging reduces carbon sequestration in Mediterranean coniferous forest. Forest Ecology and Management 262: 2287-2296. - doi: 10.1016/j.foreco.20 11.08.023

Sinsabaugh R, Moorhead D (1994). Resource-allocation to extracellular enzyme production - a model for nitrogen and phosphorus control of litter decomposition. Soil Biology and Biochemistry 26: 1305-1311. - doi: 10.1016/0038-0717(94) 90211-9

Sinsabaugh RL, Lauber $\mathrm{CL}$, Weintraub MN, Ahmed B, Allison SD, Crenshaw C, Contosta AR, Cusack D, Frey S, Gallo ME, Gartner TB, Hobbie SE, Holland K, Keeler BL, Powers JS, Stursova M, Takacs-Vesbach C, Waldrop MP, Wallenstein MD, Zak DR, Zeglin LH (2008). Stoichiometry of soil enzyme activity at global scale. Ecology Letters 11: 1252-1264. - doi: 10.1111/j.1461-0248.20
08.01245.X

Smith NR, Kishchuk BE, Mohn WW (2008). Effects of wildfire and harvest disturbances on forest soil bacterial communities. Applied and Environmental Microbiology 74 (1): 216-224. doi: 10.1128/AEM.01355-07

Soil Survey Staff (2014). Keys to soil taxonomy $\left(12^{\text {th }}\right.$ edn). USDA Natural Resources Conservation Service, US Government Printing Office, Washington, DC, USA, pp. 366.

Turgay OC, Lumbanraja J, Yusnaini S, Nonaka M (2002). Effect of land degradation on soil microbial biomass in a hilly area of south Sumatra, Indonesia. Soil Science Plant Nutrition 48 (5): 769-774. - doi: 10.1080/00380768.2002.104092 69

Turner MG, Hargrove WW, Gardner RH, Romme WH (1994). Effects of fire on landscape heterogeneity in Yellowstone National Park, Wyoming. Journal of Vegetation Science 5: 731-742. doi: $10.2307 / 3235886$

Vance ED, Brookes PC, Jenkinson DS (1987). An extraction method for measuring soil microbial biomass. Soil Biology and Biochemistry 19: 703707. - doi: 10.1016/0038-0717(87)90052-6

Wardle DA, Ghani A (1995). A critique of the microbial metabolic quotient $\left(9 \mathrm{CO}_{2}\right)$ as a bioindicator of disturbance and ecosystem development. Soil Biology and Biochemistry 27: 16011610. - doi: 10.1016/0038-0717(95)00093-T

Wu J, Joergensen RG, Ponamerening B, Chaoussod R, Brookes PC (1990). Measurement of soil microbial biomass $C$ by fumigation-extraction. An automated procedure. Soil Biology and Biochemistry 22: 1167-1170. - doi: 10.1016/0038-0717 (90)90046-3

Yang S, Zheng Q, Yang Y, Yuan M, Ma X, Chiariello $N R$, Docherty $K M$, Field $C B$, Gutknecht JLM, Hungate BA, Niboyet A, Roux $X$, Zhou J (2020). Fire affects the taxonomic and functional composition of soil microbial communities, with cascading effects on grassland ecosystem functioning. Global Change Biology 26 (2): 1354-1013. - doi: 10.1111/gcb.14852

Yokobe T, Hyodo F, Tokuchi N (2018). Seasonal effects on microbial community structure and nitrogen dynamics in temperate forest soil. Forests 9 (3): 153: 1-17. - doi: 10.3390/f9030153 